Note: This is an electronic version of an Article published in Business and Society Review $117: 2,233-280(2012)$

\title{
Corporate responsibility and compliance with the law: land, dispossession and aftermath at Newmont's Ahafo project in Ghana ${ }^{1}$
}

\author{
Radu Mares*
}

\begin{abstract}
An important part of responsible business practices is compliance with the law. This article details what actually happens when the laws of the host country fail to ensure adequate protection. The focus here is on land dispossession and loss of livelihood in relation to a gold mine project in central Ghana. How come that a well-known international company - Newmont - with its own CSR statements sets up a project in the year 2003 that displaces subsistence farmers from their land without compensating in cash or with replacement land? The analysis identifies the factors that lead the company to not compensate farmers for their lost land: cost-cutting, strict adherence to the law, CSR commitment that was new and not internalised, complexities of the Ghanaian land tenure system, peer pressure to preserve the status quo, selection of an 'old school' CSR manager, and the inadequacy of Ghanaian mining law to account for relatively novel, 'open pit' mining techniques. However, the specter of famine raised by civil society activism, the involvement of the International Financial Corporation, and a better qualified CSR team constitute another set of factors that lead to a comprehensive package of livelihood improvement measures. There is a contrast between the complexity, long-term and advanced type of assistance Newmont currently envisages and the backward, short-term, formalism and brutality of denying compensation for land back in 2003. This research is based on the extensive documentation Newmont makes available on its website, interviews conducted in Ghana, and literature research.
\end{abstract}

* Radu Mares is a Senior Researcher at the Raoul Wallenberg Institute of Human Rights and Humanitarian Law, Lund, Sweden. E-mail: radu.mares@ rwi.lu.se. 


\section{Introduction}

Gold is by far the most important mineral in Ghana, which is Africa's second-biggest producer of gold after South Africa. ${ }^{2}$ The Ahafo gold mine, a 100\% Newmont-owned project, is located in a densely populated, rural area in the Brong-Ahafo region, the Asutifi district, in central Ghana. Newmont's exploitation is a large one and because of using surface-mining technology it displaced a considerable number of people.

This article discusses a choice made by the company in 2003 as the project crystallised and got the go-ahead from regulators: to pay no compensation to the farmers for their land. The purpose is to explain how that was possible and see what has been done about it since then. This inquiry is guided by a few questions: what were the legal obligations in Ghana at the time (2003-2004)? What international standards existed at the time? What CSR commitments did the company make at the time? What was the industry custom on this issue in Ghana? How did Newmont seem to reason at the time, meaning what were the key factors leading to the company's original stance on land issue and later its change of course in dealing with displaced farmers? What corrective measures has Newmont taken since? This research is based on the extensive documentation Newmont makes available on internet, interviews the author conducted at the mining site at Ahafo and in the capital, Accra, in November 2008, and literature research. ${ }^{3}$

The purpose of this article is twofold. First, to set the record straight on the land dispossession issue. Much has happened around the Ahafo project since 2003-2004 and in the last few years Newmont has received accolades for its CSR efforts. ${ }^{4}$ It is unusual to find a mining company employing 130 staff only in its Environmental and Social Relations (ESR) department, setting up ten multistakeholder committees covering areas such as compensation, gender, agricultural inputs, social development etc, ${ }^{5}$ and publicly releasing documentation that takes one more than a week full-time to read. ${ }^{6}$ However, these commendable initiatives did 
not exist when the mine started, people were dispossessed of their land without compensation and it was not at all clear what, if anything would be done to restore their livelihood. These facts have not been properly documented in the CSR literature and thus leave a gap in anyone's attempts to understand Newmont's CSR operations at Ahafo. Second, exposing wrongdoing at a certain point in time is important; equally important is to grasp the process of change through which the people living in vicinity struggle to improve their lives.

Only the issue of compensation for land will be detailed in this article; this is not a comprehensive treatment of the various impacts of mining and of CSR initiatives undertaken at Ahafo. Indeed, a multitude of impacts and flashpoints exist: local employment (especially of the youth), compensation, access to water, access to land, inward migration, rising prices, artisanal miners, security issues, tax exemptions, procurement and awarding of contracts, resettlement facilities, effectiveness of various social programs undertaken by the company, cultural change following arrival of a large industrial complex, etc. ${ }^{7}$

\section{The Ahafo context}

The Ahafo project, on which exploration began in late 1990s, delivered its first gold in 2006 and is expected to last for 20 years. ${ }^{8}$ As this is an 'open-pit' mining project, it automatically makes use of much more land than underground mining; ${ }^{9}$ the mining facilities cover 2,426 hectares of farmland. As a result, a large number of people have been impacted. At Ahafo, the company displaced around 10.000 people and classified ten communities in the vicinity of the mining installations as 'directly impacted' by the project. The current project at Ahafo (Ahafo South - Stage I) is set to expand in coming years (Ahafo North - Stage II) with roughly 10.000 people more expected to be displaced. Newmont ${ }^{10}$ is the largest employer in the region directly employing 2000 people while its contractors employ another 2000 people. It produces half a million of ounces of gold a year. ${ }^{11}$ Newmont's Ahafo mine is the second largest gold producer in Ghana after Goldfields' Tarkwa mine. ${ }^{12}$ 
The impacts of such a large mine in a heavily populated area are correspondingly significant and varied. The local economy is predominantly agrarian with $77 \%$ of the employed working-age population in agriculture and $96 \%$ of those employed in other sectors identifying agriculture as their secondary occupation. ${ }^{13}$ The Opportunities Industrialization Centers International (OICI), a US-based NGO active at Ahafo, articulated a profile of the affected people:

The populations residing in this concession area are in general poor subsistence farmers, with low incomes due to low production on small family farms, limited non-farm income generating opportunities, and low educational status. The welfare profile (quality of life indices) of the local villages is extremely low and some basic facilities such as potable water supply, sanitation and health facilities are not available. The communities, in general, are highly dependent on subsistence-farming, and exploitation of forestry products and only a few community members are directly employed or even "employable" by any industry and the mine due to the low level of skills available in the communities. ${ }^{14}$

The most detailed source on who lost what due to the Ahafo project is the Resettlement Action Plan (RAP) - a voluminous document prepared by the Canadian consultancy planningAlliance for Newmont. ${ }^{15}$ Impacted people are classified as physically displaced or economically displaced. The figures show that the number of impacted households is 1,701 households (9,575 people), of which 823 households (5,185 people) were physically displaced as they lost both residential buildings and cropped fields in the Mine Area and 878 households (4,390 people) became economically displaced through the loss of cropped fields. ${ }^{16}$ Of the physically displaced, a majority have been provided with new houses in the two main resettlement sites at Ntotoroso and Kenyase with the rest choosing to relocate on their own and get compensation in cash. Both the resettled and the economically displaced can become vulnerable; the World Bank recognised already in 1990 the dangers of involuntary resettlement: 
Development projects that displace people involuntarily generally give rise to severe economic, social, and environmental problems: production systems are dismantled; productive assets and income sources are lost; people are relocated to environments where their productive skills may be less applicable and the competition for resources greater; community structures and social networks are weakened; kin groups are dispersed; and cultural identity, traditional authority, and the potential for mutual help are diminished. Involuntary resettlement may cause severe longterm hardship, impoverishment, and environmental damage unless appropriate measures are carefully planned and carried out. ${ }^{17}$

A dislocation of this magnitude can impose serious hardship on the local population so appropriate compensation is a crucial issue. For the sake of clarity a few more distinctions must be made as compensation can be due for residential buildings and other structures on the land, for crops, and for land itself. It should be noted that residential land on which the house is built has not been an issue. ${ }^{18}$ Furthermore, compensation for destroyed structures has been only relatively a contentious issue. On the one hand, Newmont provided replacement houses in line with Ghanaian regulations ${ }^{19}$ and World Bank standards on an 'area for area' basis designed in such a way to allow further extensions. The housing details have been negotiated in the Resettlement Negotiation Committee. ${ }^{20}$ On the other hand, only speculative structures, that is, those that people build for the sole purpose of getting compensation rather than inhabitancy and normal use, continue to raise tensions; this raises only logistical challenges to the company as they are built by the hundreds in a short period of time, but the principle is clear: speculative structures do not give rights to compensation after the cut-off date. Finally, the lack of compensation paid to households for agricultural land has been highly contentious. This has been possible due to inadequacies in Ghanaian laws, some of them being changed with the arrival of the new Mining Law in 2006.

Another distinction worth making regarding the contentious issue of compensation for land at Ahafo refers to the type of agricultural land: land that is actually used to grow crops and, under the rotational crops of agriculture, land that is left unused for 
several years to regain fertility. The latter is referred to as uncropped land or 'fallow' land. Numerous writings on the Ahafo project discuss in detail whether and how to compensate for fallow land ${ }^{21}$ and this could create the impression that cropped land has been compensated. This is not the case: both types of land were not compensated.

\section{Corporate reasoning for not compensating}

How come that a well-known international company ${ }^{22}$ with its own CSR statements ${ }^{23}$ sets up a project that displaces subsistence farmers from their land without compensating or providing them with replacement land? The key factors are discussed below.

\subsection{Keeping the costs down}

During an interview in Accra, a high level manager who was not at the site during the compensation negotiations in 2003-4, answered the question whether there was an internal division between the ESR staff and the rest of the management over the issue of land compensation as following: 'I don't think it was any division, it was just a matter of we had to keep our costs down to make the project economic and we had to follow the law. Those were the two drivers that were framing what we were trying to do...24

\subsection{Following the law}

Without having a chance to analyse the legal instrument that transferred land to the mining project $^{25}$ it is difficult to clarify in detail legal aspects of the land transfer. ${ }^{26}$ This notwithstanding, the possible legal grounds can be identified, and the inadequacy and complexity of the Ghanaian land tenure system can be highlighted. This will suffice for the purposes of the present analysis that aims to establish who was legally required to pay compensation, and the foreseeability in 2003-2004 of the damage incurred by uncompensated households. This issue of legal entitlements is key for understanding the true extent of 
vulnerability of the local population and some difficulties the company confronted. Deficiencies of local laws and uncertainty on legal entitlements are often encountered in less developed countries, so this discussion carries insights to CSR evaluations in other industries and countries.

\subsubsection{Legal framework for expropriation of land}

The Constitution of Ghana (1992) lays down the right to private property (Art. 18) and the principle of prompt, fair and adequate compensation. ${ }^{27}$ Despite seemingly clear constitutional safeguards, farmers at Ahafo actually received no compensation for land. That was due to legal loopholes and the complexities of the Ghanaian land system. ${ }^{28}$

Under the 1986 Mining Law, it is the government who takes over the land. ${ }^{29}$ The law provided for the compensation of various losses, but deliberately omitted land per se from the list. ${ }^{30}$ As the RAP notes, 'No Act provides for compensation for the land itself.,

To properly understand expropriation in Ghana, the mining law is read in conjunction with the State Lands Act, 1962 (Act 125) ${ }^{32}$ and the Administration of Lands Act, 1962 (Act 123). ${ }^{33}$ There is a significant difference between Act 123 and Act 125 in terms of compensation: while the latter provides for lump sum compensation, ${ }^{34}$ the former provides only for annual payments (e.g. royalties) to land owners, which importantly are not individual farmers or families but the traditional authorities.

All indications point to the government using Act 123 to acquire land which to some it appears as expropriation in disguise and without proper compensation. Act 123, according to Kwame Gyan, a Ghanaian expert, is an 'ingenious devise for appropriating the use of land to the Government without the radical step of divesting titleholders of their titles. ${ }^{35}$ A Ghanaian legal expert commented on this law and a related litigation ${ }^{36}$ by saying that section 10 (1) of Act 123 'is grossly inconsistent with the constitutional regime on the protection of property rights. ${ }^{37}$ 
To whom is compensation payable and in what form? The overlapping rights over land under Ghanaian customary law need to be discussed.

There is no lump compensation, but compensation in the form of land rents and royalties. They are payable to the traditional authorities, not to individual farmers or households; farmers losing access to their land receive a one-time compensation for their lost crops. The rents are derisory. ${ }^{38}$ However, royalties are more significant and are split according to a formula among traditional authorities and district assemblies. ${ }^{39}$ Still the amount resulting from royalties is small compared with the local needs. ${ }^{40}$ Furthermore, because the law delivers little accountability of how recipients - whether traditional or public authorities - use these revenues there is no guarantee that people will actually see development benefit from this collective compensation. ${ }^{41}$

The issue of legal entitlements over land is important when discussing compensation. What rights do the farmers who lost access to land have? Customary law is very important in the land tenure system in Ghana. ${ }^{42}$ The complexities and uncertainties associated with customary law ${ }^{43}$ are only exacerbated when a massive expropriation takes place displacing hundreds of households. Usually, it is traditional authorities (stools and clans) who have the title on land ("allodial" title) ${ }^{44}$ and they pass lesser rights farther down to individuals. Once allocated to a member of the land-holding community or even a stranger who has obtained an express grant from the land-holding community, the beneficiary (the user of the land) acquires very broad and virtually perpetual rights (usufruct) over the land: ${ }^{45}$

The Ghanaian usufruct is inheritable, alienable and potentially perpetual. The usufruct is described as a burden on the allodial title. According to this view, the usufruct is not another specie of ownership in itself but consists of perpetual rights of beneficial user of land, which now co-exist with the allodial title... Indeed so extensive are the rights of the usufructuary that it has been contended that where there is a usufruct over stool or family land, there is only a remote possibility of the reversionary interest of the stool or family "resurrecting", save where 
the usufruct is extinguished. In this regard, the usufruct reduces the allodial title to a nominal value. This is critical in determining entitlement to compensation and quantum for lands affected by mining activities. ${ }^{46}$

\subsubsection{Expropriation of land at Ahafo}

Further complicating the picture at Ahafo is the pre-existing legal status of stool lands. For various reasons customary land can be "vested" in the President and correspondingly moved in a different legal regime. ${ }^{47}$ It is unclear whether the land at Ahafo was under the direct administration of the traditional authorities or has been, by Executive Order, 'vested' in the President with the latter having administration rights over lands. ${ }^{48}$ As the RAP explained,

Vested Lands are lands owned by a stool, but managed by the state on behalf of the land owning stool. The legal rights to sell, lease, manage, collect rent have been taken from the customary landowners by the application of specific laws on that land and vested in the state. The landowners retain an equitable interest in the land (i.e. the right to benefit from the land). This category of land is managed in the same way as State Lands. ${ }^{49}$

This seems important because if the land at Ahafo was vested in the President, that appears to provide yet another legal ground facilitating the conversion of land from agriculture to mining purposes without proper compensation or consultation of affected communities. ${ }^{50}$

In fact, the legal status of land came up in discussions between the mine and local population as early as $1998 .{ }^{51}$ There the chiefs and farmers asked questions about compensation for land and were explained that the land is vested in the government. An official from the regional Land Valuation Board (LVB) explained the legal situation. ${ }^{52}$ Compensation would come to traditional authorities in the form of royalties, rents, and 'drinks.' He further recognised that chiefs hold allodial title on land but the farmers have usufructuary rights; it is normally this later right which is lost during acquisition. The official reckoned that it would be prudent for chiefs not to collect compensation for land to the 
detriment of these rightholders but allow the usufructuaries to claim compensation for land they have been occupying over the years. ${ }^{53}$

In another meeting, an assemblyman explained that under the mining law and the State Lands Act of 1962 every [minerals-rich] land is vested in the government and can be acquired for development. Mining companies therefore do not pay compensation on land per se but pay compensation for affected crops and also pay royalties to the central government. ${ }^{54}$ Finally, a company representative is quoted as saying that it is the government that makes the acquisition and mining companies pay royalties to the government and do not know anything about the executive instrument that the government uses to acquire land for mining operations. This is purely a governmental affair. ${ }^{55}$

However this adherence to law did not legitimize Newmont's operations and did not make the problem of dispossession without compensation go away. It was clear that the legal scheme of compensation was contested, unfair and about to change soon. One of the leaders of the farmers at Ahafo, when asked during an interview about the company's position on land compensation during the 2003-4 negotiations, said: 'Whenever you go and talk to them, they will show you the law. THE LAW. So it got to a point that we even wrote letters to the minister on the compensation because we thought the farmers have been cheated... They quoted the law and told us 'your own law says that land should not be paid.' Therefore I say we decided to also attack the law... ${ }^{56}$ Actually, as early as the late 1990 s minutes of stakeholder meetings at Ahafo recorded that assemblymen were writing petitions to the Parliament on land compensation and ownership aspects. ${ }^{57}$ By the time Newmont decided in 2003 to go ahead with the minimalist requirements of the law on compensation issues, the compensation logic was already questioned in the capital, Accra. Thus the RAP notes: 'In 2003, the national government drafted amendments to the Minerals and Mining Law on various issues, including compensation. The proposed amendments are with the Attorney 
General awaiting submission to Parliament. ${ }^{58}$ Subsequently, the mining law was modified in 2006 to include compensation for lost land. ${ }^{59}$

There is a complex legal picture that emerges at Ahafo. Farmers had rights they could rely upon under customary law. However, the land might have been "vested", and thus administered by the government, in law if not in practice. ${ }^{60}$ Furthermore, the 1986 mining law was silent on compensation for land per se and envisages compensation only to traditional authorities in forms of royalties and rents with people benefiting from development projects thus funded. The constitutional principle of prompt, fair and adequate compensation was questionably applied in this context ${ }^{61}$ and more broadly the government seems to have a poor record on compensating for land. ${ }^{62}$ The complexities and contradictions of the land tenure regime ${ }^{63}$ apparently discouraged Newmont from seeking an equitable solution at the time ${ }^{64}$ and added one more reason to go with the minimalist requirements of the law and pay no compensation for land.

\subsection{Deference to the customary land tenure system}

Why land-for-land compensation was not an option for Newmont? The World Bank recommends land-for-land for displacement taking place in farming areas. A high-level manager at Newmont argued: 'we were very concerned that we would not be as interventionist as we could be basically destroying the traditional system and land tenure rights. It sounds like an excuse but it really was one of the guiding principles: look, the system is going to work, there is land, people are going to have cash, they'll get land and get farming again. ${ }^{65}$ To be precise, the availability of cash refers to compensation Newmont paid for crops and structures as there was no cash paid for land. Along similar lines, the RAP notes:

Like the Company, these traditional authorities recognize the fact that, if the Company were to attempt to replace land for land for all households with farm holdings in the Mine Area, it would create additional problems that could effectively destroy the established mechanisms for land 
allocation and potentially cause serious inflation in the price of land in the area. Therefore, the Company will not purchase replacement farmland for economically displaced households. Instead, the traditional authorities have publicly stated and made it known to Project-affected persons/households that they, the traditional authorities, have land available for allocation for those that need it... [and] have encouraged farmers seeking land for agriculture to come forward for consideration. ${ }^{66}$

\subsection{Reliance on coping strategies for dispossessed farmers}

A consultancy document dated mid-2004 could be read as showing that the company considered cash-for-land compensation rather than land-for-land due to land-shortage.

The Ahafo Project Area is heavily populated... To maintain the livelihood of those affected farm settlers it is necessary to provide them with alternative lands of equal quality and productivity. With the exception of the surrounding forest reserves, virtually all lands suitable for farming in the vicinity of the proposed Ahafo Mine have owners and are being farmed presently or fallowed for future farming. In recognition of this land shortage, NGGL proposes to compensate affected owners of land with cash, calibrated to reflect displaced productivity. In recognition that the mine must provide alternative sites for settlement of displaced homesteads, and anticipating that some affected owners may desire to continue farming in the area, NGGL wants to learn the location, size, and relevant characteristics of presently unused land, which might be used for land compensation. ${ }^{67}$

Later on, the RAP made in 2005 an opposite assessment writing that 'The Company's own investigations have confirmed the existence of uncultivated land... [L]and cover in Project area includes some $13,460.6$ hectares of fallows and natural areas, equivalent to $80 \%$ of the area covered by the satellite image. ${ }^{, 68}$

Whatever the availability of land there was, the winning argument seems to have been 'why bother?' and the company was content to rely on a number of coping strategies for disposed farmers. It was about individual and collective self-help, of making use of uncultivated land and of traditional institutions. 
According to the company, dispossessed farmers were expected to group themselves, approach their traditional authority and together allocate new lands - this 'is only one of several coping mechanisms available to farmers, but it is the only mechanism with which the Company can assist. ${ }^{69}$ Thus Newmont envisages that groups of farmers, together with their village traditional leader, would approach their chiefs and present their needs for land; the company would facilitate the grouping of farmers and assist in land allocation performed by traditional authorities. As the RAP recounted, the company expected traditional leaders to make land available; the company would then play a facilitating role. ${ }^{70}$

Furthermore, the company expected that 'impacted farmers may be coping with cultivated land losses by clearing their own fallow lands or by clearing fallow land held by members of their extended family. ${ }^{71}$ Candidly acknowledged is that 'The Company has not inventoried the total landholdings of resident and non-resident households, and as a result is not in a position to assess how significant a loss the Mine Area is to these households (i.e. how much of their total landholdings are lost), and therefore how "easy" it will be for them to cope. ${ }^{72}$ Such were the gaps in Newmont's knowledge: 'The extent of exterior fallows, as well as farm fields located outside the Mine Area, held by households is unknown. ${ }^{73}$ Furthermore, Newmont acknowledged: 'The impacts on communities, families, and individuals from a loss of fallow are not known. The fallow land use system in the Mine Area will not be fully understood without further monitoring and study. ${ }^{74}$

Besides facilitation, the company considered monitoring of self-relying strategies as critical: 'The monitoring dimensions of the above strategy are critical. Through the monitoring program, the Company will track those households for which alternate land does not become available. ${ }^{, 75}$ Through 'twice yearly land acquisition surveys to assess overall landholdings ${ }^{, 76}$ to be undertaken by the OICI as well as communicating with local NGO's such as ActionAid and Guards of the Earth and the Vulnerables, the company intended to 
monitor how farmers coped with dispossession. 'The results of the monitoring program will allow the Company to identify and track those that do not appear to be coping well., ${ }^{, 7}$

In sum, Newmont counted heavily on self help and coping strategies: farmers were to clear fallow land on own family land and use it for agricultural production, to contact chiefs to get new land from stool land, and to enter tenancy agreements with owners of their choice.

\subsection{Aligned with the industry custom}

One of the early measures Newmont undertook in Ghana was to assess how its peers in the mining industry handled compensation. Company employees went on information tours at other mines and a Ghanaian industry insider was hired as the top negotiating manager at Ahafo. As a Newmont employee commented on the situation, 'Newmont is not the only mining company in Ghana. There are others that have worked in this country for 100 years no one has ever compensated anybody for land. Everyone pays crop compensation., ${ }^{78}$

A farmer representative gave his account on the compensation negotiations that took place in 2003-4. Specifically on the compensation for land issue, he highlighted the twin obstacles of law and industry custom:

At that time we'd sit down and we'd talk but the problem was that it did not exist in the laws of Ghana. At the end of the day we did not have any basis to tell the company that people lost land because all they were saying 'this is the law, you have it in your own country, no compensation for land' and they were saying that Obuasi [a large mine of Anglo Gold Ashanti] is not doing it... they don't want to change the status quo. Newmont does not want to change and affect other mining companies... The laws of Ghana say you should not pay for land; other companies don't do it, why should Newmont go ahead and pay? That was the negotiation, the main argument. ${ }^{79}$

An employee at Newmont who was not part of the 2003-4 events commented:

- It was difficult under the circumstances for Newmont to jump in and say 'we are going to pay for land'. What does it mean for the other companies? This is my own guess about the situation: 
under the circumstances, if I were in charge..., I'd play it safe and say 'let's not muddy the waters. That's what the law says.'

- You mean Newmont stirred some kind of opposition from other companies in Ghana?

- Not exactly. It's natural when you go into any area you'd want to know what rules and regulations pertain and you'd want to be seen as someone who respects the way that people do their things in that area. If you want to get into something new you ask 'how do I do this?' and they put before you the law and that's what you follow. If I were doing it, that's what I'd do: I'd ask 'what does the law say on this?'

- Even if you know that following the law will destroy the livelihood of people around the mine?

- Exactly. So now you started by the law and you sit back and say 'I satisfied the law' what else can I do to help the people so that's what the CSR means... I'm saying this is probably what happened. ${ }^{80}$

A study of mining in Ghana hinted at these dynamics in the different context of compensation for crops. There the government through the Land Valuation Board (LVB) applies its own method of valuing crops which is widely criticised in Ghana as grossly inadequate.

Mining companies in Ghana face a difficult choice. Should they view the LVB compensation levels as a fixed requirement or merely a minimum level of acceptable compensation? Opinion within the Ghanaian mining community is divided. Both Newmont and AngloGold Ashanti stated during interviews that they adhere to GCG (Ghanaian Central Government) compensation policies and do not provide more. Newmont, in particular, indicated that it feels uncomfortable providing compensation in excess of the amount prescribed by law. It fears that doing so would set a negative precedent and create problems with the GCG and the communities in which it operates. ${ }^{81}$

A manager at Newmont commented on the more recent experience of Newmont with its peers. Thus, commenting on state owned enterprises, he said: we organise occasionally workshops on land resettlement and compensation and entities like DRA (the governmental electricity authority), the highway authority... you know, they have to put up their way of operating against mining companies, like us and Gold Fields, and not 
necessarily liking it because they have to go through much more trouble than they used to before: "oh bring the police in and move them out". 82

\subsection{The 'cultural broker'}

In 2009 documents commissioned by Newmont state unequivocally: 'A common finding at many sites is the power of a single individual to positively or negatively impact Newmont's relations with communities. The importance of approachable, concerned, responsive individuals cannot be overemphasised. ${ }^{83}$ Back in 2003, Newmont's negotiating team at Ahafo was lead by a Ghanaian, Mr. Akwasi Gyima-Bota, with wide experience in the mining industry. A Newmont manager explained that Bota

was here with previous companies - Normandi, Tercenary... He was involved in the Ahafo project since 1996 and I think the expats around just saw him as the source of all things Ghanaian. He is actually a sub-chief in his own area and he is very knowledgeable about traditional protocols and he was the only senior Ghanaian manager we had at that time coming from the previous company. So "if Akawsi said it's ok', if there is a problem he can go and sort it out." ... Remember, we are an American company, new to Africa... I've seen it before where such an entity would come in and almost get charmed by the first person that comes along and think that's the way it has to be in Ghana. So people in that role become cultural brokers and become focal points for better or worse. ${ }^{84}$

However, both company employees and a farmer representative resisted the notion that Newmont's minimalist approach to compensation could be laid at Bota's doorstep. A corporate manager in the ESR department explained that the decision making power on these land compensation issues back in 2004 was indeed placed in Ghana, not at the headquarters in Denver, and the whole team rather than a single person reached decisions: 'In that time everybody was involved in those decisions... We never really had a structure where one person makes these decisions, it's more of a consensus-based thing... I would be hesitant to 
put all the blame on one person... It was the company's decision. It took advice... It was not just him... I see him more as a broker that we relied on too much. ${ }^{85}$

Another manager was asked about the role of Bota and the failure of judgement in Newmont back in 2003 as the decision to displace without compensation for land was taken. Without being a direct participant in the negotiations, he said:

'I don't think it was a failure. I think it was a corporate decision that has now come back to bite us. Bota was the man who executed it, but it was at the highest level - the priority was "just get the people off the land." ... I'm sure he did not do it alone, he advised and was given the go ahead. He would not have done anything without authorisation... Yeah, they [Newmont] chose him... But that's the sensitive part. Sometimes people do what they are told instead of telling people the right thing that has to be done... He should have known better. But you need some kind of resilience and grace to be able to do that. ${ }^{86}$

Bota has left the Ahafo site in 2004 and the company in 2007. The same interviewee commented: 'You think he was sacrificed? He was put on woodpile, they burned the guy's ass... Because of... Image. Was he a liability...? Big liability. You think he was more or less innocent responding to the pressures of the company? He has also his own personal style, but very strong character, extremely articulate individual... But the decisions he made... Fundamental to how the company was viewed. So I can't blame the company for this. They [Newmont] selected him, the buck stops with them. ${ }^{87}$

\subsection{CSR commitments neither internalised nor fulfilled}

In October 2003 the company released its CSR policy and commits, among others, to 'respect the Universal Declaration of Human Rights [UDHR] in its business operations', to 'wherever appropriate and feasible, set operating standards that exceed the requirements of the local law', to 'assess our performance against our policies and standards' and to 'demand leadership in social responsibility from all our people. ${ }^{, 88}$

Newmont's Guidelines accompanying its CSR policy resemble the first two principles of the Global Compact: 'We will work toward achieving the ability to assure that 
we do not breach the principles underlying the UDHR and are not otherwise complicit in human rights abuses. ${ }^{89}$ Newmont was to accede to the Global Compact only later, in June 2004, though it seemed to be already well anchored in the international CSR discourse. Thus the Guidelines explicitly reference a number of well-known international CSR initiatives such as the Extractive Industries Transparency Initiative, the Publish What You Pay campaign, the Voluntary Principles on Security and Human Rights, the Global Reporting Initiative and the AA 1000 standard on stakeholder engagement.

Any farmer at Ahafo would be hard pressed to see how Newmont worked in the spirit of the Universal Declaration, which reads: 'No one shall be arbitrarily deprived of his property. ${ }^{90}$ Conspicuously absent from the list above ${ }^{91}$ is the World Bank's Operational Directive 4.30 (OD 4.30) on involuntary resettlement, from 1990, which was widely acknowledged as international good practice and which clearly states that 'Displaced persons should be compensated for their losses at full replacement cost prior to the actual move'. ${ }^{92}$ The RAP would in 2005 recognise the international best practice status of the OD 4.30, but would curiously continue that 'The Company's demonstrated commitment to meeting Ghanaian legislation and international best practice, as defined by Operational Directive 4.30, contributes to maintaining a Social License to Operate. ${ }^{93}$

Actually, this statement is partial with the truth: when it came to housing and residential land, Newmont complied with the OD 4.30, but regarding compensation for farming land it conveniently disregarded the Banks' standard. ${ }^{94}$ The latter envisages providing rural, farming communities either replacement land (land-for-land), or cash (cashfor-land); as will be shown later, Newmont created a third category in the form of facilitating access-to-land seen as necessary for improving or restoring livelihoods. 


\subsection{Not contemplating consequences: spectre of famine}

By 2005 newspapers reported that food production in the area went down drastically, the population doubled, and the cost of living raised - all due to the Ahafo project. People around the mine were interviewed and most were concerned about the affordability and availability of food in the area. ${ }^{95}$ Nevertheless, by the same time the RAP wrote reassuringly that 'Food security is not a critical issue in the area. Most farmers in the Mine Area are able to meet food consumption needs with their own agricultural production. Twelve percent of homesteads experienced food shortages in the past year., 96

The company eventually acknowledged the threat of famine and its response was mainly the Agriculture Improvement and Land Access Programme (AILAP) - a program that facilitates access to land. In the words of a Newmont executive, AILAP 'was done after the fact when we realised there were issues. (...) Originally the guidance for the ship was "pay for crops and structures"... The word that we had was that there was plenty of land around that people would get through traditional means with the compensation. I think you're seeing a paradigm shift at that point, in the middle of the project we realised there was a problem. ${ }^{97}$

\section{Reactions to dispossession}

\subsection{Farmers}

An OICI report noted that displaced farmers expected compensation for land itself, including in the form of cash-for-land, and manifested their disposition to continue farming elsewhere:

The farmers' concept of adequate compensation includes compensation for land and not only payments for crops and landed property destroyed... A lot of anxiety is expressed about being provided alternative land for farming activities. They even express anxiety about having to buy food if relocated as they currently feed from their farms. Most of these farmers have indicated that they cannot undertake any other economic venture. Consequently they anticipate compensation for their land in order to migrate to areas where they could obtain new land for 
farming. Residents are of the opinion that there is an abundant supply of land and that they are capable of securing alternative land to continue their farm business as long as they are adequately compensated for their crops and current land. This may abate the land use conflict envisaged. Consequently inhabitants of the project area suggest that if they are adequately compensated they should be able to migrate to continue their farm business elsewhere in the region if not in the same district. ${ }^{98}$

\subsection{Civil society}

A farmer representative at Ahafo recounted the support from civil society groups in 20032004. Apparently it came in several flavours. One was support for regulatory change in Accra: We could see that the land issue created all sorts of problems. Mining law says that all land belongs to government ... that land could be taken for good - it was a very bad law. So some of us decided that we had to fight to have this law changed. So we took some of our men to Accra, we collaborated with TWN [Third World Network] and we had a press conference, we got the ministers, all those big men - the Minister of Mines, Chamber Of Mines and other people around and had a press conference to send the message to them that Newmont is paying only crops, they are not paying for land and that the law was very bad ... there was a whole lot of problems because they were not paying for land, they were taking the land for free and for good.

Another aspect relates to the information that NGOs could provide to farmers at Ahafo who, it should be remembered, had no previous experience with mining and its impacts. The same farmer representative recalled that 'as for the land compensation they [NGOs] did not talk much about it because it was in the law. They advised us on resettlement, on crop compensation, how negotiation is going to be, they took us to Tarkwa [largest mine in Ghana] and showed us some people... suffering... But the land issue was a very sensitive issue because the law in Ghana was not talking about land... 99

More of the NGOs' position on the Ahafo project can be gleaned from the impressive mobilization of NGOs in 2005 as the International Finance Corporation (IFC) was considering granting a loan to Newmont. ${ }^{100}$ From the exchanges of civil society groups with 
the IFC it is clear that the issue of replacement land figured prominently in NGOs concerns. They wrote in a letter that 'Over $95 \%$ of the families displaced by the Ahafo South mine depend on rotational crop, subsistence farming for their livelihoods. There is no question that replacement of land is essential to restoration, let alone improvement, of the livelihoods of the affected populations. ${ }^{101}$ Another report cautioned that 'Land replacement measures critical to restoring the livelihoods of the displaced farmers remain incomplete or uncertain, posing an immediate threat to food security in the region. ${ }^{102}$ FIAN drew attention to the project's noncompliance with OD 4.30 on involuntary resettlement:

Access to land is a major issue for both physically and economically displaced persons. According to OD 4.30, the living conditions of displaced persons have to be at least restored and "land for land" approaches are the preferred option. In the case of the Ahafo project, "land for land" is the only feasible option to restore livelihoods. Without major modifications regarding access to land, compensation, and development projects, this project will not be in compliance with OD $4.30 .^{103}$

Furthermore, Newmont

insists that there is no legal obligation for the company to provide land and that it is not prepared to purchase land for economically displaced persons. It will rather facilitate access to arable land through the traditional system. This process of facilitation will be monitored. This approach ignores the fact that gaining access to land through the traditional system entails costs for the households... Any costs related to that have to be born either by the state or the company. ${ }^{104}$

Detailed comments were made about a suitable land replacement plan; among them is also the issue of rights over land: 'We want to emphasize that to be effective in restoring long-term livelihoods, any land replacement strategy must provide security of land tenure or transferable usufruct rights to those people whose lives and livelihoods were irreversibly altered when Newmont Ghana took over the land they occupied to extract a profit from it., 105 


\subsection{International Finance Corporation}

The IFC got involved at Ahafo well before granting the 125 mil USD loan to Newmont in January 2006. It seems to have been as early as May 2004. ${ }^{106}$ Newmont was not in compliance with the World Bank's standard on compensation for land. Apparently the IFC raised concerns but they were rebuffed.

As the spectre of famine was rising the role of IFC became critical. Newmont acknowledged the instrumental role played by the IFC in helping them put together a package to firstly avoid impending famine and secondly to restore and improve livelihood of displaced populations. Newmont sought IFC's involvement less for the loan but for its expertise and stamp of approval. ${ }^{107}$ After proper compensation according to World Bank's standards became a forgone issue, the IFC worked with Newmont on the encompassing issue of livelihood improvement.

I think they [IFC] recognised that at that point we decided we will not compensate for fallow land but they said 'ok, we recognise that it's going to be a problem so you guys you need to do a study of alternative ways of dealing with fallow land'... We, I think some of us accepted a long ago that we will have to compensate for fallow land but you know there were some harder hands (heads?) who said 'it's not required by law' and nobody has ever done it in Ghana. No mining company or anybody else for that matter. ${ }^{108}$

A farmer representative recounts how farmers' expectations aligned with IFC's expertise and suasion. Deprived of legal backing to claim compensation for the land itself, farmers struggled for better compensation for crops during negotiations with the company, ${ }^{109}$ within the framework provided by Ghanaian law; in addition, they expected some development assistance from the company to get back to farming:

At that time we were not hinting that we want compensation for land. We knew the law was bad so we thought that even if Newmont was not going to pay for land, we had to fight for better compensation for crops on the land... and suggest other programs that would help people to develop... When we even started fighting on this land issue, they said they paid for what the law 
demands they should pay. They were always quoting the law "this is the law and we are safe". And I also said: “as a social and corporate citizen, let's also look at how best we can develop the people. If I'm a farmer and I lose my land for good even if the law says..., for convenience sake and good relations it costs me to get another land to farm."

At the time IFC undertook its own inquiries and interviewed affected farmers. The farmers' representative commented:

We told them [IFC] that even though Newmont has paid for crops, Newmont did not pay for land. People have lost their land for good and we think, as social workers, that Newmont could do something to help the farmers to re-engage in farming because if I'm a farmer and want to change my profession it will be difficult. I don't know anything apart from farming from my childhood... IFC went back - they came in 2005 - and when they came back, it was Newmont who called us again and said they would implement programs; IFC also advised then that it would be in the best interests of the company to give people land to work on. ${ }^{11}$

Besides its expertise IFC also instituted a twice per year independent review at Ahafo. ${ }^{112}$ As a result, starting with 2005, all programs the company undertakes at Ahafo are assessed by independent consultants and reports are publicly released on the corporate website. ${ }^{113}$

\section{The aftermath: towards the livelihood restoration}

\section{package}

Newmont evolved its strategy in face of the hardship that land dispossession has caused. When NGOs and the press warned that the area faces a risk of famine and the IFC confirmed the seriousness of the situation, the company changed gears and put in place a more comprehensive approach.

\subsection{The land access package}

Land is the centrepiece of any package aimed at restoring and enhancing livelihood of affected farmers. Newmont explains: 
Under Ghanaian law and practice, the Company is not required to purchase required land, or to compensate for required land per se. Instead, the Company is required to compensate for assets affixed to the land: i.e., crops and structures. Notwithstanding its legal obligations, the Company recognizes that loss of land is of critical importance for impacted persons/households, particularly those with land-based livelihoods, and has devised a strategy to ensure the provision of replacement land in kind. ${ }^{114}$

Newmont gradually developed its 'Farmland Access Strategy' which eventually came to contain three main land access assistance options: (1) Private Access to Land by using the customary sharecropping system; (2) Traditional Authority Land Bank with temporary and free access to community land for two years; and (3) Mining Area Land Bank with temporary and free access to company land for two years.

First seems to have been a 'land bank' made available by traditional authorities. Newmont signed a Memorandum of Understanding with the Traditional Authorities of Ntotoroso and Kenyase No. 2 that provides access to land in designated "Royal Lands" to all compensated farmers that Newmont identified as having no land. Farmers would be allowed on two acres of stool land for two years after which the farmer could negotiate with the Traditional Authority a long-term sharecropping agreement. This land bank covered 677 acres. $^{115}$

Second, Newmont outlined the concept of 'land bank' on company land, i.e. in the Mine Take Area. This measure, explained in the RAP in August 2005, was another temporary measure offering land for two years. It referred to land unused in the Mine Take area ('land not critical to operations over the next two to five years') and allowed farmers who received compensation for crops to continue farming their lands if they could not secure access to land outside the Mine Take Area. Newmont identified some 800 acres of such land. $^{116}$ 
Third, in May 2006, Newmont began the AILAP, described below. ${ }^{117}$ This program proved the only viable component of the three pronged strategy. It created a set of incentives that proved compelling enough for farmers to not pursue the other two temporary options.

\subsection{The comprehensive development package}

By early 2006 Newmont had implemented a new comprehensive approach well captured in this statement: 'The Company has defined a number of livelihood enhancement initiatives to help Project-affected persons/households re-establish their livelihoods or create new ones, and long-term community development initiatives to assist communities, local and regional government, and traditional council in the Project Area establish social programs and infrastructure. ${ }^{118}$ Most attention and top priority was given to project-affected-people (PAP), i.e. people who lost land, be they physically or economically displaced. These programs will be introduced below to explain when they started, what they provide, and who is covered; a detailed presentation and a critical assessment are beyond the scope of this article. ${ }^{119}$

The Agricultural Inputs and Land Access Program (AILAP) ${ }^{120}$ began in May 2006 and is implemented by the US-based NGO OICI. When a farmer has obtained access to at least two acres of land - from a landowner of choice, traditional authorities or the company in the Mine take area $-\mathrm{s} /$ he can apply to AILAP for an agricultural assistance package. This package contains cash, ${ }^{121}$ various agricultural inputs, and training. It should be emphasized that AILAP does not own itself any land and farmers do not become owners of land by joining AILAP; also this assistance is a one-time payment. Newmont reports that by 2009, $96 \%$ of farmers who were displaced and compensated (3,295 farmers) have participated in the program and are now back on the land farming. ${ }^{122}$ A farmers' leader acknowledged the program during an interview, least the small size of land being facilitated: 
At the end of the day you are planting a permanent crop - cocoa, citrus - they are giving you to plant. You pay for the 'drinks', AILAP gives you the money to go and pay. So that's why I'm saying it is a very good program but the land in question is too small... So Newmont has done well in implementing the program but you look at it critically and think that 2 acres to plant is too small... ${ }^{123}$

The Livelihood Enhancement and Community Empowerment Program (LEEP) ${ }^{124}$ commenced on 15 February 2005 and is implemented by the OICI. It targets both physically displaced and economically displaced households. The four objectives are: (1) to enhance livelihood capacities through small and medium enterprise development (including vocational and technical skills training) and increased agriculture production (more intensive farming); (2) to enhance human capabilities through interventions to improve health, nutrition and education; (3) to enhance community resiliency and participation by building the capacity of communities (the social/organization capacity and attitudinal/motivational capacity of community members) to deal with the change and shocks associated with mining projects, and also provide training to ensure sustainability of the program itself; and (4) to stimulate community development by preparing a larger sustainable community development plan to maintain and enhance the quality of life for those residing outside of the immediate Project Area. $^{125}$

The Vulnerable Program was established in January 2006 and is implemented by the Ahafo-based Guards of the Earth and Vulnerable (GEV). It is focused on directlyimpacted households experiencing 'severe hardship' and living within the mine area, particularly in the resettled communities. The Program provides 'a safety net until identified transitionally vulnerable households can become self-sufficient and resilient to economic stresses. Each household should have a place to live, means of income, access to medical care, and ability to feed itself. ${ }^{126}$ Concretely, the company provides a food basket, health insurance and medical treatment, payment of school fees, vocational training, micro-credit etc. ${ }^{127}$ 
Ahafo Agribusiness Growth Initiative (AAGI) began in March 2006 and is implemented by the NGO African Connections Ghana Ltd. ${ }^{128}$ AAGI 'aims to develop the commercial agriculture skill of these institutions [farmer-based organizations and small and medium enterprises] and to link them to financing sources and market. This is with the intention of creating a vibrant local economy that will ultimately create job and income opportunities independent of the mine. ${ }^{129}$ In the first phase it delivered 'high impact training covering agricultural productivity, farmer business skills, and business management skills'; subsequently it also aimed to strengthen groups and farmer associations in the production of five crops (chilli pepper, soybean, ginger, maize, and plantain) which have high productivity potentials and ready markets. Training is mainly for farming (productivity training and business skills training) but also for Small and Micro Enterprises (business skills training). The AAGI project was targeted not narrowly on project-affected-people, but on directed affected communities (eight communities in South Ahafo). By 2009, Newmont reported that 2,600 farmers have taken advantage of this program. ${ }^{130}$

The Ahafo SME Linkages Program (ALP) began in February 2007 as a theeyear program funded by Newmont and IFC. ${ }^{131}$ It aims to support local small and medium enterprises (SMEs). The main components are local procurement (Newmont adopted a standard operation procedure to increase its buying from local businesses), local supplier development, and strengthening of business associations. ${ }^{132}$ The program identified some SMEs that would benefit most from this initiative in the following sectors: agribusinesses, "hospitality" (inns, hotels and catering services), fisheries, and masonry and construction. ${ }^{133}$

Finally, the Ahafo Social Responsibility Agreement (ASRA) ${ }^{134}$ has its origins in Newmont's decision in late 2005 to set up a Sustainable Development Foundation; the company promised $1 \%$ of gross operational profit plus 1 US\$ per ounce produced to fund development initiatives beginning in 2006. It was estimated that 650,000 USD yearly will go 
into the Fund. ${ }^{135}$ In January 2006, Newmont set up the Ahafo Social Responsibility Forum (ASRF), a 56-member organisation consisting of representatives from Newmont, government, traditional leaders and the community, 'to provide the Community with the opportunity to participate in the Company's decisions and plans, deliberate on issues of mutual interest, help build strong communication and decide on how the Community Development Fund is to be allocated. ${ }^{136}$ After time-consuming work to set up a complex governance structure, three agreements have been signed in May 2008: a foundation agreement setting the terms of using the 650.000 USD per year accumulating in the Community Development Fund, ${ }^{137}$ an employment agreement on how Newmont should increase local recruitment, and an encompassing relationship agreement on how stakeholders at Ahafo should interact. ${ }^{138}$ In terms of beneficiaries covered, the ASRA agreements go beyond project-affected-people but remain limited to the directly affected communities. These agreements aim to comprehensively regulate corporate-community relations and therefore they cover stakeholders in both the district of Asutifi where mining commenced in 2006 and the district of Tano North where Ahafo Stage 2 project is yet to begin production.

\section{Implications for the responsibility to respect human}

\section{rights}

How did Newmont's decision to not compensate for land and its subsequent change of course fare with the corporate responsibility to respect human rights? The responsibility to respect human rights has featured in CSR instruments such as the revised OECD Guidelines (originally published in 1976) and the 1999 Global Compact, but achieved prominence in the 2008 framework of the UN SRSG, John Ruggie. He writes that 'to respect rights essentially means not to infringe on the rights of others - put simply, to do no harm... To discharge the responsibility to respect requires due diligence. This concept describes the steps a company must 
take to become aware of, prevent and address adverse human rights impacts. ${ }^{139}$ This concept presented in 2008 cannot be applied retroactively to Newmont's decisions in 2003, but one can take this case study as an opportunity to meditate about the application and implications of this responsibility in a surface-mining mining context. Several observations can be made.

First, on the relationship between corporate and state responsibilities, the SRSG explains that 'the corporate responsibility to respect exists independently of States' duties', ${ }^{140}$ such as the state's own responsibility to regulate on proper compensation for land. Following the law offers no defence to a company supposed to respect human rights; this is particularly the case when the law is dispositive rather than imperative. Indeed Ghanaian law did not prohibit the payment of compensation but it was merely silent on the issue; were the law imperative, issues of national sovereignty would arise. ${ }^{141}$

That the law did neither compel nor prohibit Newmont to compensate for land is clear enough. The law was flawed in the 2003-2004 period and it was revised in 2006; it is now explicit on compensating for land not only for crops, and for both cropped and uncultivated land. Newmont's employees now openly admit that how the land issue was dealt with in 2003-4 was improper but stress that the company aimed to comply with the law. What happened is that Newmont followed the 'law of the land', that is public regulation and industry custom. It is the local custom that actually prohibited compensation for land. Newmont's falling in line with Ghanaian custom was not about satisfying the law, but the rest of the industry who was enjoying the status quo. It was respect for the status quo. Not only private industries might have a stake in the status quo but also the government itself, in its role of economic actor rather than lawmaker:

The land compensation system in Ghana is broken... The central problem is that the levels of compensation are too low. Yet the state has an interest in artificially keeping these rates low, because it is the largest entity required to pay compensation. By requiring high levels of monetary compensation, the state would circumscribe its own ability to engage in public works 
projects... For some issues, such as land compensation valuations and revenue management, it is clear why the central government would not wish to change the status quo. ${ }^{142}$

A second observation has to do with what respecting human rights might mean in the context of displacement. The land taken by Newmont without compensation appears as an infringement of the right to property, or in the Ghanaian context, perpetual usufruct rights over land under customary law. Such rights are also enabling rights in the meaning that the livelihoods of families in that rural setting depend on the farming land. Dispossession is bound to have ripple effects on a number of economic and social human rights in the period following dispossession. ${ }^{143}$ So the issue of compensation for lost assets is relevant from a human rights perspective in two ways: first, strictly from a right to property angle, deprivation of land without compensation is a human rights violation, and second, these losing of these assets (neither replaced nor compensated) result in a multitude of human rights (e.g. access to food, to education, to health, generally the right to a decent standard of living) being undermined.

In the case of enabling rights such as the right to property, the responsibility to respect operates at different stages: once early on, at the time of displacement, when the enabling right has to be respected and then later on, at the time when life post-displacement has stabilised but when another set of economic and social human rights are endangered by abusive displacement and must be respected. While it is impossible for Newmont to argue that the Ahafo project complied with the responsibility to respect at the initial stage, the company has a continuing responsibility to respect the other economic and social rights undermined by dispossession. At this later stage, the equivalent of 'respecting human rights' of the displaced people is taking due diligence measures aimed at 'livelihood restoration'. Newmont's comprehensive development package described in a previous section represent arguably a promising, possibly a successful, model of due diligence, of fulfilling the corporate responsibility to respect human rights in the post-displacement period in the mining context. 
Finally, it is interesting that Newmont seems now to be at the cutting-edge of what due diligence actually means when it comes to livelihood restoration. CSR managers often state that their company has 'learned from mistakes' but in Newmont case it seems that the initial misguided choices did set up a context that magnified the already challenging tasks facing Newmont's ESR team and bred, almost forced, innovations in CSR practice and strategic thinking. So while the company maintained a strict position on the land compensation issue ${ }^{144}$ and to definitions of vulnerability, it appeared more flexible and open to laying the building blocks of sustainable farming communities, especially the 10 directly affected by the mine. The company appears now able to pursue a more encompassing strategy to economic empowerment, development of social services and institutional strengthening (through partnerships with communities and public authorities). The ESR team at Ahafo has no less complex task than laying the building blocks for an improved livelihood through participatory and capacity-building measures necessary for a functioning, sustainable community that was deeply shaken when the mine construction began.

Newmont had a choice between following the inadequate Ghanaian law and the international standards of the World Bank/IFC. It chose the least demanding and showed lack of leadership internationally ${ }^{145}$ and nationally ${ }^{146}$ that made a mockery of its own CSR policy. This hard, minimalist position in 2003-2004 was softened in 2005 when the surrounding communities came on the brink of famine and the company, guided by the IFC, began a complex process of livelihood restoration. This complex package delivered at Ahafo now positions Newmont in a genuine leadership position given the commitment in manpower of the ESR team at Ahafo, the breadth of the projects, the multistakeholder consultative and decision-making structures used, ${ }^{147}$ and the advanced reasoning exposed by interviewed employees of Newmont. 


\section{Conclusions}

In 2003, Newmont took the decision to not compensate farmers for their lost land. This decision was affected by a combination of factors: cost-cutting and a strict adherence to the law were the main drivers for Newmont. The commitment to CSR was new and clearly not internalised in the company, a disconnect further aggravated by a number of compounding factors: complexities of the land tenure system, peer pressure to preserve the status quo, selection of an 'old school' CSR manager at Ahafo standing for Ghanaian tradition and industry custom and acting as 'cultural broker', and a recent switch in mining techniques from underground to open pit that left the Ghanaian law lagging behind until its revision in 2006.

In 2004-2005, a set of new factors - the specter of famine raised by civil society activism, the involvement and advice of the IFC and a new, larger and better qualified CSR team - began to emerge. The result was a package of livelihood improvement measures. At these later stages, the company seems to have deliberately avoided a compensation mind-set: it took a minimalist approach to access to land ${ }^{148}$ and generally avoided being bogged down in every-single-thing-you-lost will be replaced or otherwise compensated individually. Newmont appeared to acknowledge that it irrevocably breached the responsibility to respect the right to property and consequently looked to the future to ensure it fulfilled its responsibility to respect livelihood rights, that is, those economic and social rights undermined by dispossession. To that end it pursued a systematic approach to development centred on economic empowerment measures, social services through the ASRA Fund and on strong relationships with all stakeholders having a role in the directly affected communities. There is a contrast between the complexity, long-term and rather advanced type of assistance Newmont currently envisages and the backward, short-term, formalism and brutality of denying compensation for land back in 2003. 


\section{Appendix: Timeline of Ahafo project}

March 1998: Public involvement with the Ahafo South Project began in a community meeting held in Bechem with assemblymen/women, chiefs, elders, farmers, and other interested parties regarding development of the Sefwi Belt and Ntotoroso Gold Projects.

1999: Normandy set crop compensation rates through consultation with a multistakeholder negotiating body, comprising representatives of traditional authorities, chief farmers, impacted farmers, the Land Valuation Board, and the Stool Lands Administration.

Since 2000: public hearings of the Environmental Protection Agency for Environmental Impact Statements and to discuss community concerns

February 2003: five-star CSR management system adopted by the Newmont group

March 2003 - February 2004: Initiation of the Resettlement negotiation Committee (RNC).

May 2003: International Council of Mines and Metals (ICMM) Principles released

13 June 2003: Newmont gets a 30-year mining lease (Ahafo Mining lease)

September 2003: Extensive OICI Livelihood Survey is realised

October 2003: Social Responsibility Policy and Guidelines, Newmont Mining Corporation

December 2003: the investment agreement between Newmont and the government of Ghana

December 2003: Newmont communicates its reputation and values in statements in Twi and English to community representatives during a durbar of Chiefs from Ahafo to introduce Newmont's Chief Executive Officer (CEO) to local people

Since November 2003: Stratcom - an Accra-based communications and public relations firm - organized a number of workshops, seminars, and public meetings for stakeholders to introduce the Company and the Project.

Late 2003: OICI begins work at Ahafo

10 February 2004: cut-off date for entitlements

10 February 2004 - 22 March 2005: RNC met 31 times

2004: Construction of mine starts

April 2004: OICI Survey

30 May - 3 June 2004: IFC becomes involved; field assessment of the resettlement at Ahafo 
9 June 2004: Newmont accedes to the Global Compact

14 December 2004 and 24 January 2005: the Company and OICI held community consultation sessions on Livelihood Enhancement and Empowerment Program (LEEP)

15 February 2005: LEEP is launched

18 February 2005: RNC concluded resettlement, compensation and relocation negotiations

April 2005: Ghana EPA issues Environmental Permit for Ahafo South

29 August 2005: Resettlement Action Plan

29 August 2005: Environmental and Social Impact Assessment

December 2005: Newmont commits 1 USD/gold ounce and $1 \%$ of net profits in a Community Development Fund

January 2006: IFC approves loan of USD 125 million to Newmont

January 2006: Ahafo Social Responsibility Forum (ASRF) is established

April 2006: Ahafo Agro-business Growth Initiative (AAGI) is launched

May 24, 2006: Memorandum of Understanding signed for Ghana Responsible Mining Alliance

May 2006: Agriculture Improvement and Land Access Programme (AILAP) is launched

July 18, 2006: Gold production starts

February 2007: Ahafo SME Linkages Program (ALP) is launched

24 April 2007: resolution of Newmont's shareholders to conduct a Community Relationship Review

December 2007: Final Environmental Management Plan submitted to EPA

May 2008: Ahafo Social Responsibility Agreement (ASRA) is concluded

\footnotetext{
${ }^{1}$ My thanks to those I had the privilege to interview in Accra and Kenyase, Ghana, in November 2008, and to Chris Anderson and Nick Flanders for kindly supplying documents useful to this research. The support provided by the Justa Gardi Fundation is gratefully acknowledged.

${ }^{2}$ See the governmental site of the Mining Authorities of Ghana http://www.ghana-mining.org. For a concise historical analysis of mining in Ghana, see Kwasi Barning, Case Study on Foreign Investment in Mining: The Case of Ghana, UNCTAD, 2001, http://www.unctad.org/infocomm/Diversification/cape/pdf/barning.pdf.

${ }^{3}$ A good, brief overview of land compensation issues is available in Michael Carson et al, Managing Mineral Resources through Public-Private Partnerships - Mitigating Conflict in Ghanaian Gold Mining, Woodrow Wilson School of Public and International Affairs, 2007, pp 30-35.

${ }^{4}$ A Business Reference Guide, Castan Centre for Human Rights Law, IBLF, OHCHR, UN Global Compact, 2008, p. 32, http://www.unglobalcompact.org/docs/news_events/8.1/human_rights_translated.pdf; Luc Zandvliet and Emma Nikki Owiredu, Ahafo Project - Brong Ahafo Region \& Akyem Project - Eastern Region, Field Visit:
} 


September 9-26, 2005, CDA, Corporate Engagement Project, 2005,
http://www.cdainc.com/publications/cep/fieldvisits/cepVisit18Ghana.pdf

${ }^{5}$ See section 5.2.

${ }^{6}$ See section 'Ahafo: Public Disclosure Documents' under rubric 'Ahafo Plans \& Results: Stage 1' at http://newmontghana.com/index.php?option=com_content\&task=view\&id=49\&Itemid=43

${ }^{7}$ For more comprehensive assessments see the Independent Reviews by Tasneem Salam and Frédéric Giovannetti prepared for the IFC available at www.newmontghana.com; The State of Human Rights in Mining Communities in Ghana, Commission on Human Rights and Administrative Justice (CHRAJ), 2008; Letter of NGOs to IFC, February 17, 2006; Zandvliet and Owiredu, supra note 4; Alan Roe and Jonathan Samuel, Ghana Country Case Study, The challenge of mineral wealth: using resource endowments to foster sustainable development, ICMM, 2007, http://www.icmm.com/document/301.

${ }^{8}$ PlanningAlliance, Resettlement Action Plan, Ahafo South Project, Summary, Newmont Ghana Gold Limited, 29 August 2005, p. 1 [hereinafter RAP]. This document contains very detailed information related to the project.

${ }^{9}$ Some estimates indicate that surface mining requires six times more land than underground mining to exploit comparable resources. George Botchie et al, Land Tenure, Land Use and Environment in Ghana, Technical Publication No. 72, Institute Of Statistical, Social \& Economic Research, University Of Ghana, Legon, 2007, http://www.isser.org/images/stories/dec2008pubs/botchie.pdf. See also Peter Claver Acquah, Natural Resources Management and Sustainable Development - The Case of the Gold Sector in Ghana, UNCTAD/COM/41, 1995 $\mathrm{http} / / / \mathrm{www}$.natural-resources.org/minerals/CD/docs/unctad/claveracquah.pdf

${ }^{10}$ Newmont refers herein to Newmont Gold Ghana Limited, the subsidiary of US-based Newmont, if context does not indicate otherwise.

${ }^{11}$ IFC Grants 125 Million Dollars Loan to Newmont's Ahafo Mine, GNA Business/Finance, 19.07.2006, http://www.modernghana.com/news/101448/1/ifc-grants-125-million-dollars-loan-to-newmonts-ah.html

12 Overall, US-based Newmont is one of the three main players besides South-African-based Anglo Gold Ashanti and Gold Fields. In 2007, Gold Fields accounted for 33\% of Ghana's gold production, AngloGold Ashanti - 21\% and Newmont - 18\%. Ghana Chamber of Mines, The performance of the Mining Industry in 2007, p. 7, ww.ghanachamberofmines.org

${ }^{13}$ For a very detailed, clear image of the people living in the project area, see RAP, supra note 8.

${ }^{14}$ Carla Denizard, Livelihood Study of Resident Farmers in the Newmont Ghana Gold Limited (NGGL) Brong Ahafo Concession, OICI, July 2004. In RAP, Annex I, p. 2, supra note 8. [hereinafter OICI Livelihood Study]

${ }^{15}$ RAP, supra note 8 .

${ }^{16}$ Id., Summary, p. 1 ,

${ }^{17}$ World Bank's Operational Directive on Involuntary Resettlement (OD 4.30), 1990, para. 2.

${ }^{18}$ When physically displaced people opted for a new house in the resettlement villages, they obtained a title to their individual resettlement plot in the form of a Certificate of Occupation. This is granted by the Lands Commission and is basically a 99-year lease for a small annual ground rent of between US\$1.41 and US\$2.17. Such practice is in line with WB/IFC standards that emphasise security of tenure. World Bank OD 4.30, Ibid.

${ }^{19}$ The Mining and Environmental Guidelines of 1994: 'Any pre-existing settlement located close to mining operations where the pre-existing inhabitant's public safety is at risk, or where the inhabitants are subjected to unreasonable nuisance, shall be resettled at a more distant site with at least an equal standard of accommodation and services at the cost of the company.' Quoted in RAP, Summary, p. 3, supra note 8.

${ }^{20}$ For a flavour of negotiations, see minutes of RNC discussions in RAP, Annex E, supra note 8.

${ }^{21}$ See for example, Kwame Gyan \& Associates, Land Use and Compensation-Study of Ghanaian Law and Implementation, Final Report to Newmont Ghana Gold Limited, May 2008; RAP, supra note 8.

${ }^{22}$ By acquiring Normandy in February 2002, the holder of exploration rights at Ahafo, Newmont became the world's largest gold producer. Renate F. Mas, 'Newmont nears last formalities of Normandy buy,' American Metal Market, 2/27/2002, Vol. 110 Issue 39, p. 4.

${ }^{23}$ See section 3.7.

${ }^{24}$ Interview no. 1.

${ }^{25}$ Resolution of the Ghanaian Parliament of Dec 18, 2003, referred to in Parliament approves investment agreement with three mining companies, GNA, 2003-12-18, http://www.modernghana.com/news/46245/4/parliament-approves-investment-agreement-with-thre.html

${ }^{26}$ It proved impossible to obtain the aforementioned Resolution and the accompanying Report of the Committee on Mines and Energy that probably show what legal instrument was used to compulsory acquire farming land. This is so despite putting significant effort with government entities, academics, civil society groups and the company. Consequently the exact legal status of the land before acquisition and the precise modality of transfer remain unclear to this author. Therefore all possible laws are analyzed.

27 'Compulsory acquisition of property by the State shall only be made under a law which makes provision for (a) the prompt payment of fair and adequate compensation; and (b) a right of access to the High Court by any person 
who has an interest in or right over the property whether direct or on appeal from other authority, for the determination of his interest or right and the amount of compensation to which he is entitled.' Art 20.(2), Constitution of the Republic of Ghana, http://www.ghanareview.com/parlia/Gconst21.html

${ }^{28}$ The main laws applicable at the time for land acquisition were, besides the Constitution, the 1986 Minerals and Mining Law (amended by the Minerals and Mining Amendment Act of 1992), the 1962 State Lands Act (Act 123) and the 1962 State Lands Act (Act 125).

${ }^{29}$ Land 'is usually acquired compulsorily by the government (through the use of legislative instruments) from traditional landowners - usually communal lands or stool lands [and] mining lease holders are usually given a minimum lease period of 30 years and have complete surface rights.' George Botchie et al, Land Tenure, Land Use and Environment in Ghana, Technical Publication No. 72, Institute of Statistical, Social \& Economic Research, University of Ghana, Legon, 2007, p. http://www.isser.org/images/stories/dec2008pubs/botchie.pdf

30 'A mineral right holder must compensate for any disturbance to the rights of owners or occupiers and for damage done to the surface of the land, buildings, works or improvements, or to livestock, crops or trees in the area of mineral operations.' Art 71 (1) of Minerals and Mining Law, 1986 (PNDC Law 153) as amended by the Minerals and Mining Amendment Act of 1992.

${ }^{31}$ Act 125 deals with the classical expropriation of property for a public purpose under the 'eminent domain' doctrine. RAP, Summary, p. 3, supra note 8.

${ }^{32}$ Kwame Gyan \& Associates, p. 48, supra note 21.

${ }^{33}$ Section 10 of Act 123 reads: ' 1 . The President may authorise the occupation and use of any land to which this Act applies for any purpose which in his opinion, is conducive to the public welfare or the interests of the state.'

${ }^{34}$ Once the land is expropriated, the previous owner of the land applies for compensation to the Land Valuation Board. N.A. Kotey, C. Dowuona-Hammond and R.A. Atuguba, Ghana Land Administration Project Legislative and Judicial Review, Kotey \& Associates, Accra, 2004; see also Kwame Gyan \& Associates, p. 48, supra note 21.

${ }^{35}$ Kwame Gyan \& Associates, p. 52, supra note 21.

${ }^{36}$ In 1999, a plaintiff sued a mining company and claimed deprivation of title for his land [Asare v Ashanti Goldfields [1999-2000] 1 GLR 474]. He was paid compensation for crops, but sued for additional compensation for the taking of the land itself. The court relied on the 1962 Administration of Lands Act [123] and found that no compensation is payable for deprivation of title in such cases. As described in Interview no. 2.

${ }^{37}$ Interview no. 2. The issue was discussed in Asare v Ashanti Goldfields. The court distinguished compulsory acquisition under Act 125, which triggers art. 20 of Constitution, versus authorization of use under Act 123, which allows for a mining lease of 30 years to commence. The interviewee considered this reasoning introduces a distinction which is shallow and without merit. During this period the owner cannot effectively deal with the land as s/he pleases (e.g. enter into a tenancy agreement or exercise any right consistent with his/her title or interest in land); de facto, if not de jure, acquisition has taken place.

The study by Kotey and colleagues which contains a thorough review of the legislative framework and case-law and finds that Section 10 of Act 123 'falls short of the stated objectives of the constitution on the mode of compulsory acquisition, conditions for its validity and the determination of the payment of compensation as stated in Article 20(1) of the constitution.’ N.A. Kotey et al, supra note 34.

${ }^{38}$ Under PNDCL 153, annual rents were $\$ 0.30 / \mathrm{km} 2$ for reconnaissance and prospecting lease holders and $\$ 0.65 / \mathrm{km} 2$ for mining lease holders. George Botchie et al, supra note 29.

${ }^{39}$ Under mining regulations applicable at the time (PNDCL 153 and its subsidiary legislative instrument, LI 1349 of 1987 ) royalties were set at between $3 \%$ and $12 \%$ of the mines' gross mineral. George Botchie et al, supra note 29. Emmanuel Aubynn notes that royalties are set at $3 \%$ of the gross sales of companies. Of all royalties paid, $80 \%$ go to the central government's Consolidated Fund and 10\% are set aside for the development of governmental and academic institutions involved in mining sector support. Thus only the remaining $10 \%$ of royalties reach local populations where they are further split according to the following formula: $6 \%$ to the District Administration that hosts mining companies, 2\% to the Traditional Council (a body of traditional rulers in the District) and 2\% to all the local chiefs of communities whose lands fall within the spheres of influence of the mines. Emmanuel Ato Aubynn, Community Perceptions of Mining: An Experience from Western Ghana, Master thesis, Department of Earth and Atmospheric Sciences, University of Alberta, 2003.

40 'Communities' share of royalties are not only insignificant to carry out any meaningful development, but also misapplied by local community leaders. Emmanuel Ato Aubynn, supra note 39 (references omitted). See also Theresa Garvin et al, 'Community-company relations in gold mining in Ghana,' Journal of Environmental Management 90 (2009) 571-586.

${ }^{41}$ Botchie and colleagues summarize the situation by noting that royalties 'are largely used by individual chiefs for their personal benefit, without any consideration for the rest of the community. This has often generated resentment among community members. These concerns have been demonstrated in various forms, ranging from 
complaints to district political authorities and traditional rulers, mining companies and the government to violent confrontations with mining companies, and open defiance against some traditional rulers, leading to their destoolment and to court actions. There is also widespread disaffection among chiefs and traditional rulers about their share of royalty payments and land rents, while mining companies have in turn expressed discontent over the distribution and use of these funds. Some communities have also grown critical of their chiefs and the district assemblies over the use of their share of the royalties. Finally, there are also conflicts among traditional authorities as a result of jurisdictional problems discussed earlier over who should be entitled to royalties.

Royalties received by district assemblies are usually paid into the general revenue pool and no special attention is given to the development of local communities... The use of royalties returned to these districts is a source of worry not only to local communities directly affected by mining, but also to mining companies. Many companies blame what they perceive as excessive demands from these communities for development projects on the failure of district assemblies to use the royalties for any meaningful investment in these communities.' George Botchie et al, supra note 29.

${ }^{42}$ 'Ghanaian customary law begins from the basic tenet that all land has an owner. In fact, nearly all land has multiple owners, with a chief holding the highest title, and numerous other rights-holders claiming lesser rights of possession, use, or transfer. This embedding of the individual's land rights within certain group or secondary rights is perhaps the major difference between customary and Western property law.' Joseph Blocher, 'Building on Custom: Land Tenure Policy and Economic Development in Ghana', Yale Human Rights and Development Law Journal, Vol. 9, p. 177, 2006 http://papers.ssrn.com/sol3/papers.cfm?abstract_id=985353 (references omitted)

${ }^{43}$ 'It is not uncommon for the rights to land, which has already been leased or rented and compensation duly paid by an investor to one allodial titleholder, to be challenged or disputed by another allodial titleholder.' Kwame Asumadu, 'Reform of Ghana's Land Tenure System,' ModernGhana, 11 May 2003, www.modernghana.com/news/112044/1/reform-of-ghanas-land-tenure-system.html; 'The prevailing tenure involves considerable tension between legislation and traditional practice, and within traditional practice between: neighboring Stools; a Stool and the extended families within that Stool; an extended family and individuals within that family.' rePlan with Opportunities Industrialization Centers International (OICI) and Ministry of Food and Agriculture, Agricultural Improvement and Land Access Program Ahafo South Project, Newmont Ghana Gold Limited, 2006, p. 2. [hereinafter AILAP]

${ }^{44}$ Kwame Gyan noted: 'An allodial title is the highest proprietary interest known to customary schemes of interest in land. It is sometimes referred to as the Paramount title, Absolute title, Ultimate or Radical title. The allodial title can be held primarily by customary communities, namely Stools and Families.' Kwame Gyan, p. 23, supra note 21; See also Joseph Blocher, supra note 42.

${ }^{45}$ Michael Carson and colleagues noted: 'While the allodial right to the land belongs to the community as a whole, individuals and families within a Stool can acquire land rights that cannot be overruled by allodial rights... Usufruct title is of unlimited duration, as long as the individual or family bloodline does not expire. Thus, the chief, in whom the allodial rights are vested, in theory, cannot unilaterally displace a usufruct holder.' Michael Carson et al, p. 30, supra note 3.

${ }^{46}$ Kwame Gyan et al, p. 25, supra note 21 (italics added).

${ }^{47}$ The reasons for vesting the land might have to do with uncertainty and conflict over land within and between traditional authorities. 'Brong Ahafo House Of Chiefs Want Right Of Lands,' ModernGhana, 29.04.1997, www.ghanaweb.com/GhanaHomePage/NewsArchive/artikel.php?ID=598

${ }^{48}$ Apparently this was the legal regime of lands acquired by Newmont: "customarily owned but state-managed lands". According to the RAP, 'land ownership in Asutifi District is legally vested in the government' as a result of Executive Instrument No. 46 of 1961. RAP, Summary, p. 4, supra note 8.

${ }^{49}$ RAP, Chapter 3, p. 14, supra note 8.

${ }^{50} \mathrm{~K}$ wame Gyan explains the change in legal status once land is vested: 'Vested Lands ... are lands previously owned, controlled and managed by stools or families, which by an Executive Instrument, have been vested in the President. The term 'vesting' ordinarily connotes the transfer of the allodial ownership to the President as trustee, not simply the management and control functions of land administration. It signifies the non-derivative title to the maximum range of liberties with respect to ownership and use of land. Generally the vesting instrument confers on the President the normal incidents of vesting, including the execution of any deed, and authorizing the occupation and use of any affected land. The legal position appears to be that upon the publication of the executive instrument, the lands cease to be stool lands or family lands as defined above. It must be pointed out that the vesting of lands in one authority does not necessarily mean the absence of lesser proprietary interests in other parties in the same land.' Kwame Gyan et al, supra note 21.

${ }^{51}$ Newmont reports that public involvement with the Ahafo South Project began with community meetings in March 1998. For minutes of various meetings, see "Attachment One - Summary of previous public outreach 
efforts" in Newmont Ghana Gold Ltd., Public consultation and disclosure plan, Ahafo south project, Prepared for International Finance Corporation, August 2005. [hereinafter Public consultation and disclosure plan]

${ }^{52}$ According to him, the applicable laws were the mining law PNDC 153/1986 read in conjunction with laws 123/1962 and 125/1962 through which the state may acquire the land or authorise its occupation and use. Minutes at the Information Workshop Between Chiefs, Assemblymen and Representative of the Towns of Yamfo, Susuanso and Techire with Centenary Gold Mining Company, 10 March 1998, in Id.

${ }^{53}$ Ibid.

${ }^{54}$ Report on the Mine Familiarisation Tour organised by the environmental division of Centenary Gold Mining Company Ltd. For chiefs, assemblymen and farmers representatives of Susuanso, 2 April 1998, in RAP, Annex E, supra note 8 .

${ }^{55}$ Id.

${ }^{56}$ Interview no. 3.

${ }^{57}$ Report on the Mine Familiarisation Tour, supra note 54; Report on the Mine Familiarisation Tour organised by the environmental division of Centenary Gold Mining Company Ltd. for teachers representatives of the towns of Susuanso and Yamfo, 14 may 1998. RAP, Annex E, supra note 8.

${ }^{58}$ RAP, Chapter 3, p. 10, supra note 8.

${ }^{59}$ The following provision of the law is understood to provide compensation for land: 'The compensation to which the owner or lawful occupier may be entitled to, may include compensation for, (a) deprivation of the use or a particular use of the natural surface of the land or part of the land...' art. 74. (1), Minerals and Mining Law, 2006 (Act 703).

${ }^{60}$ According to the RAP, 'land ownership in Asutifi District is legally vested in the government; nevertheless, in practice, customary ownership dominates.' RAP, Chapter 3, p. 13, supra note 8 .

${ }^{61}$ N.A. Kotey et al, supra note 34.

${ }^{62}$ It was noted that 'The most serious problem associated with compulsory acquisition is the failure of Government to make prompt and adequate payment of compensation and the crippling backlog in compensation claims.' Institutional Arrangements, Land Sector, Ghana, Land Administration Project program, World Bank, 2004, p. 16. (references omitted) [hereinafter Institutional Arrangements] According to the World Bank, records indicate that in the past the government has defaulted in most cases and failed to pay full compensation or provide assistance for the resettlement of displaced persons. RAP, Chapter 3, p. 9, supra note 8 .

${ }^{63}$ Michael Carson et al, p. 33, supra note 3. A 2004 report notes that the land sector has continued to be beset by major problems and constraints involving: general lack of discipline in the land market, indeterminate boundaries of stool/skin lands, compulsory acquisition by government of large tracts of lands, inadequate security of land tenure, difficult accessibility to land, weak land administration system, lack of consultation with land owners and chiefs, lack of consultation, coordination and cooperation among development agencies, and inadequate coordination with neighbouring countries. Institutional Arrangements, supra note 62, pp. 16-17.

${ }^{64}$ See sections 3.2. and 3.4 below.

${ }^{65}$ Id.

${ }^{66}$ RAP, Chapter 7, p. 10, supra note 8, (emphasis added).

${ }^{67}$ SGS Environment, Identification of Compensation Land, July 2004 (emphasis added), in RAP, Annex K, p. 1, supra note 8 .

${ }^{68}$ RAP, Chapter 7, p. 10, supra note 8.

${ }^{69}$ Id., p. 11.

${ }^{70}$ The company considered three ways of facilitation. First, facilitate the grouping of farmers who have been compensated and have lost land through the development of the Project. The traditional authorities have stated they support the grouping of farmers for land allocation purposes, rather than dealing with single farmers one at a time. Second, group farmers under a village traditional leader (e.g Chief of Kwakyekrom or Chief of Kodiwohia) so that these leaders, together with the farmers seeking land, would approach their respective traditional authorities to present their needs for land in hectares per farmer and proposed use of the land. Third, assist in land allocation by the traditional authorities to these farmers. Id., p. 10.

${ }^{71}$ Id.

${ }^{72}$ Id., p. 11.

${ }^{73}$ Id., Chapter 4, p. 48.

${ }_{75}^{74}$ Id., Chapter 7, p. 9.

${ }^{75}$ Id., p. 11.

${ }^{76}$ Id.

${ }^{77}$ Id.

${ }^{78}$ Interview no. 4

${ }^{79}$ Interview no. 3. (emphasis added)

${ }^{80}$ Interview no. 4. 
${ }^{81}$ Michael Carson et al, supra note 3, p. 31.

${ }^{82}$ Interview no. 1.

${ }^{83}$ Gare A. Smith and Daniel Feldman, Community Relations Review, Final Global Summary Report, Newmont Mining Corporation, $\quad 2009, \quad$ pp. www.beyondthemine.com/2007/pdf/CRR_Final_Global_Summary_Report_March_2009.pdf

${ }^{84}$ Interview no. 1.

${ }^{85} \mathrm{Id}$.

${ }^{86}$ Interview no. 5.

${ }^{87}$ Id.

${ }^{88}$ Newmont Mining Corporation, Social Responsibility Policy and Guidelines, October 2003, in RAP, Annex A, supra note 8.

${ }^{89}$ Ibid.

${ }^{90}$ Art. 17(2), Universal Declaration of Human Rights.

${ }^{91}$ Also absent are the ICMM Development Principles adopted in may 2003 which provide a company should 'Uphold fundamental human rights and respect cultures, customs and values in dealings with employees and others who are affected by our activities' (Principle 03) which entails, among others, to 'Minimise involuntary resettlement, and compensate fairly for adverse effects on the community where they cannot be avoided.' http://www.icmm.com/our-work/sustainable-development-framework/10-principles

${ }_{92}$ World Bank OD 4.30, para. 3.(b) (i), supra note 17 (emphasis added).

${ }^{93}$ RAP, Chapter 3, p. 16, supra note 8.

${ }^{94}$ Even less seriously can be taken a presentation made before a CSR conference in 2006 that a Newmont manager co-authored: 'The most significant sustainable development and community relations challenges the company faced, and in retrospect one of the most costly, was the resettlement and compensation of people living within the mine footprint. For the first time, Newmont had to relocate a significant number of people in order to carry out its mining activities on a rural greenfields project. However, even before the investment decision had been made, and the potential scale of the resettlement and compensation effort was fully understood, Newmont made a strategic decision that it would compensate and resettle or relocate project-affected people according to World Bank/IFC and Equator Principle standards. These standards go far beyond those of the Ghanaian government, and they require not only that people be compensated for loss of shelter and economic livelihood, but that the affected people be actively included in all discussions and major decisions related to how they will be compensated. A Resettlement Action Plan, identifying impacts and solutions, was developed to address the IFC requirements.' David B. Cox et al, Integrating Corporate Citizenship into MNC'S Risk Assessment and Management Processes: A Case of Newmont Mining in Ghana, Symposium paper, Ghana, 20-22 November 2006.

${ }^{95}$ Clement Boateng, 'Artificial Famine Hits Newmont Ahafo Project Area,' Ghanaian Chronicle (Accra), June 2, 2005, http://www.minesandcommunities.org/article.php? $\mathrm{a}=1345$

${ }^{96}$ RAP, Chapter 4, p. 44, supra note 8.

${ }^{97}$ Interview no. 1.

${ }^{98}$ OICI Livelihood Study, p. 12, supra note 14

${ }^{99}$ Interview no. 3.

100 See, for ex, Letter of NGOs to IFC, February 17, 2006, www.fian.de/fian/downloads/pdf/gold/Ahafo_Letter_to_KaldanyKyte-Feb1706.pdf; see also Communities' Concerns/Comments: Environmental Impact Assessment on the Ahafo Mine Prepared for IFC by Newmont, $\begin{array}{lllll}\text { Letter from } & \text { Farmers, } & 26 & \text { October } & 2005 \text {, }\end{array}$ http://www.fian.de/fian/downloads/pdf/gold/051026_Ahafo_COMMUNITIES_CONCERNS.pdf

${ }^{101}$ Letter of NGOs to IFC, supra note 100.

${ }^{102}$ Newmont Mining: Big Promises, Disappointing Returns, A progress report by EARTHWORKS and Oxfam America, April 2006, p. 2, http://www.nodirtygold.org/pubs/Newmont2006Progress.pdf

${ }^{103}$ FIAN, Newmont's Ahafo South gold mining project in Ghana - Documentation of Violations of the Human Rights to Food and Water, Recommendations to the Board of Directors of the International Finance Corporation (IFC), 2005, p. 13, http://www.fian.de/fian/downloads/pdf/gold/051117_Ahafo_docu_FIAN.pdf ${ }^{104} \mathrm{Id}$.

${ }^{105}$ Letter of NGOs to IFC, supra note 100.

${ }^{106}$ One external review of the resettlement occurred during an IFC field assessment from 30 May to 3 June 2004.

107 According to IFC, Newmont could have finished the project without the loan, but wanted the agency's stamp of approval for meeting social and environmental standards. Celia W. Dugger, 'IFC Loan for Foreign Mining in Ghana Approved,' New York Times, 1 February 2006, http://www.minesandcommunities.org//article.php?a=1400 
${ }^{108}$ Interview no. 1.

${ }^{109}$ Compensation for crops destroyed by mine operations remains one of the most contentious issues at Ahafo. Asutifi Concerned Farmers Assoc., Petition Against the Payment of Crop Compensation by Newmont-Kenyasi, 29.06.2003, http://kenyasi.com/Kenyasi-2003-10-07-03.html; Alhaji Kofi Mensah, 'Payment of Compensation to Affected Mining Communities', Ghanaian Chronicle (Accra), 28.02.2008, http://allafrica.com/stories/200802280610.html

${ }^{110}$ Interview no. 3.

${ }^{111} \mathrm{Id}$.

${ }^{112}$ See also Letter of NGOs to IFC, Re: Terms of Reference for Independent Monitoring of the Ahafo Project, June 12, 2006, http://www.fian.de/fian/downloads/pdf/gold/Comments_TOR_Ahafo.pdf

113 www.newmontghana.com

${ }^{114}$ RAP, Summary, p. 14, supra note 8

115 Ailap, p. 10, supra note 43.

${ }^{116} \mathrm{Id}$

${ }^{117} \mathrm{Id}$

${ }^{118}$ RAP, Chapter 2, p. 1, supra note 8.

${ }^{119}$ For assessments, see IFC's twice-yearly assessments starting with 2005, supra note 7 .

${ }^{120}$ Agricultural Improvement, supra note 117.

${ }^{121}$ A company employee explained that there are ' 3 types of cash payments. First, the drink money for 2 acres, so 75 Ghana cedis (around 50 USD) for 1 acre. Then we help with land clearance money - money to help the farmer do the initial land preparation. That depends on the kind of vegetation we find on the land ... the farmer is present and records are taken. So it ranges between and 600 and 800 cedis. And the third one is to help the farmer maintain the farm, to control weeds on the farm. It is paid when the farm has been established and the planting material has actually been put on the field. That's 100 cedis, a flat rate, onetime payment. All the package we give is a 1-time payment. The intention is to help the farmer kick start the farming.' Interview no. 4.

122 Newmont, Fact Sheet: Newmont Ghana's Akyem Project, 31 January, 2009, http://newmontghana.com/images/stories/pdf/newmont_ghanas_akyem_project_fact_sheet_31jan2009.pdf

${ }^{123}$ Interview no. 3.

${ }^{124}$ See for more details RAP, Annex P, supra note 8.

${ }^{125}$ Id.

${ }^{126}$ rePlan Mining Consultants Ltd (rePlan), Resettlement Action Plan, Amoma Project, Ahafo, Ghana, 2009 , p. 23 , http://newmontghana.com/images/stories/pdf/final_preliminary_resettlement_action_plan_amoma_feb_09.pdf.

${ }^{127}$ Tasneem Salam and Frédéric Giovannetti, Independent External Social Compliance Monitoring, 7th review, February/March 2008, p. 5 http://newmontghana.com/images/stories/ahafo_pdf/indext_social_compliance_monitoring_report_february-march_2008_ahafo_south_project.pdf

${ }_{128} \mathrm{http} / / /$ newmontghana.com/index.php?option=com_content\&task=view\&id=16\&Itemid=32

129 The status of Ahafo Agribusiness Growth Initiative (AAGI) http://newmontghana.com/index.php?option=com_content\&task=view\&id=130\&Itemid=32

${ }_{131}^{130}$ Akyem Fact Sheet, supra note 122.

http://www.ifc.org/ifcext/pressroom/ifcpressroom.nsf/PressRelease?openform\&E4A72BD062B780C88525727C $0061 \mathrm{ECA5}$

132

www.newmont.com/en/operations/ghana/ahafo/docs/indreviews/IndExt_Social_Compliance_Monitoring_Report_November_2008-Ahafo_South_Project.pdf

${ }_{133}$ Tasneem Salam and Frédéric Giovannetti, Independent External Social Compliance Monitoring, 6th Review, July 2007, http://www.newmont.com/en/operations/ghana/ahafo/docs/indreviews/IndExt_Social_Compliance_Monitoring_Report-July-2007-Ahafo_South_Project.pdf

${ }^{134}$ Newmont, The Ahafo Social Responsibility Forum (ASRF)

http://newmontghana.com/index.php?option=com_content\&task=section\&id=18\&Itemid=40

${ }^{135}$ Newmont Ghana Gold Ltd., Social and Community Development of the Ahafo Region, Collaboration to Promote Project Benefits - Vision and Commitments, Prepared for International Finance Corporation, October 2005, p. 6, newmontghana.com/images/stories/ahafo_pdf/supplemental/Social_and_Community_DevelopmentAhafo_South_Project.pdf

${ }^{136}$ Ahafo Social Responsibility Forum (ASRF), supra note 134.

137 The Forum decided on the following allocation of funds: Human Resource Development - 24\% (e.g.: scholarships, training for farmers); Provision of Infrastructure - 23\% (e.g.: maize dryers, silos, roads, clinics, schools, toilets); Provision of Social Amenities - 18\% (e.g.: community centres, police posts, libraries); Economic Empowerment - 17\% (e.g.: assistance with establishing businesses, factories, credit facilities, market 
stalls); Protection of Natural Resources - 12\% (e.g.: reforestation, environmental awareness programmes); and Support for Cultural Heritage - 6\% (e.g.: support for festivals, upgrading of palaces). Ahafo Social Responsibility Forum (ASRF), supra note 134.

${ }_{138}$ The texts of the three agreements are available at http://newmontghana.com/index.php?option=com_content\&task=view\&id=199\&Itemid=40

${ }_{139}$ Protect, Respect and Remedy: a Framework for Business and Human Rights, Report of the Special Representative of the Secretary-General on the issue of human rights and transnational corporations and other business enterprises, A/HRC/8/5, 2008, paras. 24, 56, http://www.reports-and-materials.org/Ruggie-report-7Apr-2008.pdf [herein Protect, Respect and Remedy] (emphasis added)

${ }^{140}$ Id., Para. 55; Ruggie continues: 'Therefore, there is no need for the slippery distinction between "primary" State and "secondary" corporate obligations - which in any event would invite endless strategic gaming on the ground about who is responsible for what.' (emphasis added)

${ }_{141}^{14}$ Id., Para 54, fn 39.

${ }^{142}$ Michael Carson et al, pp. 33 and 55, supra note 3.

${ }^{143}$ Farmers petitioned in 2003 the minister of mines in Accra: 'we will be deprived of our crops and farm lands forever, and this will certainly affect our livelihood particularly our ability to feed our children and take care of them in school.' Asutifi Concerned Farmers Assoc., Petition against the Payment of Crop Compensation by Newmont-Kenyasi, 29.06.2003 (emphasis added) http://kenyasi.com/Kenyasi-2003-10-07-03.html.

${ }^{144}$ This article traced these due diligence measures from the time when land was taken 'for free and for good', to the early and feeble due diligence grounded in a 'self-help', 'coping' mindset of 2004-2005, to the comprehensive package aimed at livelihood improvement informed by the IFC expertise of 2006. With Newmont's emphasis on access to land rather than right to land, and on providing inputs limited to 2 acres of land rather than a larger surface reflecting lost land of each farmer, the company's access-to-land program has been explicitly acknowledged as not being about compensation, but a famine-avoidance tool; thus the program could not repair the violation of the right to property but became an essential part of the restoration package aimed at safeguarding the multitude of human rights which were threatened by the loss of an economic base provided by land.

${ }^{145}$ A World Bank overview of the mining industry at that time (2004) showed Newmont lagging behind its peers and noted that 'There is a slowly emerging trend among companies to address the issue of forced resettlement, and to compensate, or even improve the incomes of, resettled populations. Instead of adopting policies on the issue of land rights and resettlement, however, many companies simply state their general support for universal human rights, implicit in which may be guarantees of land and resettlement rights.' Thus Alcan, Anglo American and BHP Billiton had explicit policies regarding resettlement and displacement, while Newmont and many others did not. Gare Smith, Dan Feldman, Company Codes of Conduct and International Standards - An Analytical Comparison, Part II: Oil and Gas, Mining, World Bank, IFC, 2004, pp. 24-25 http://siteresources.worldbank.org/INTPSD/Resources/Angola/Angola_CompanyCodesofConduct.pdf

${ }^{146}$ See sections 3.2 and 3.5 revealing Newmont's reluctance to challenge the status quo in Ghana in relation to compensation for land and the emphasis placed on meeting the minimum requirements of a flawed Ghanaian law.

${ }^{147}$ Radu Mares, 'From charity to institutional development: Reflections on Newmont's CSR strategies and conflict-avoidance in Ghana' in Human Rights: Pre-Conflict, In Conflict, and Post-Conflict, I. Boerefijn, L. Henderson, R. Janse, and R. Weaver, eds. (Cambridge, Antwerp, Portland: Intersentia, 2012).

${ }^{148}$ No ownership of land was transferred but access to land was emphasised, and help (hand-outs) to farmers through the transition period was very circumscribed to vulnerable people only. Note though that Newmont, to its credit, turned a blind eye to the well-known partition of family land between family members so each member can access his/her own AILAP package. 